TABLE VIII.-Follow-up Micturating Cystourethrograms of Gross and Moderate Reflux

\begin{tabular}{|c|c|c|c|c|c|c|}
\hline \multirow{2}{*}{\multicolumn{3}{|c|}{$\begin{array}{c}\text { Time } \\
\text { Interval }\end{array}$}} & \multirow{2}{*}{$\frac{\text { Gross }}{\begin{array}{c}\text { Reflux } \\
\text { Ssopped }\end{array}}$} & \multirow{2}{*}{$\frac{\text { Reflux }}{\begin{array}{c}\text { Reflux } \\
\text { Continued }\end{array}}$} & \multicolumn{2}{|c|}{ Moderate Reflux } \\
\hline & & & & & $\begin{array}{l}\text { Reflux } \\
\text { Stopped }\end{array}$ & $\begin{array}{c}\text { Reflux } \\
\text { Continued }\end{array}$ \\
\hline $\begin{array}{l}6 \text { months } \\
12 \text { months } \\
2 \text { years } . . \\
4 \text { years } . \\
5 \text { years } .\end{array}$ & $\begin{array}{l}\ldots \\
\cdots \\
\cdots \\
\cdots\end{array}$ & $\begin{array}{l}. \\
\cdots \\
\cdots \\
\cdots\end{array}$ & 1 & $\begin{array}{l}1 \\
2 \\
2 \\
2\end{array}$ & $\begin{array}{l}4 \\
6 \\
2 \\
6\end{array}$ & $\begin{array}{l}3 \\
3 \\
1 \\
2\end{array}$ \\
\hline Total & . & . & 1 & 7 & 18 & 9 \\
\hline
\end{tabular}

\section{Discussion}

The classification of vesicoureteric reflux into the three grades of severity-gross, moderate, and slight-has provided a valuable guide on which treatment can be based. Our results have shown that the grossly refluxing ureter is accompanied by a high incidence of initial renal damage and, if this reflux is allowed to continue, may lead to depressed renal growth and further loss of renal substance.

The kidneys of ureters showing slight or moderate reflux do not appear to be associated with initial or progressive renal changes, but the numbers involved in this study are not sufficient to be certain of this point. Our findings, however, would suggest that this type of reflux in the infant has a reasonably good prognosis.

The results of follow-up micturating cystourethrograms would support the opinion expressed by Stephens (1962) that there is a strong tendency for spontaneous cessation of reflux in the course of several years, and it may well be that the ureter showing moderate vesicoureteric reflux and renal damage in childhood was, in fact, a grossly refluxing ureter in infancy.

Most writers have strongly emphasized the part that infection plays in producing the renal damage, and there can be little doubt that vesicoureteric reflux is an important mechanism by which infection of the bladder reaches the kidney. In support of this concept is the finding of pyelotubular backflow of contrast into segments of the renal parenchyma which we found on several occasions during micturating cystourethrography. Hodson (1965) concluded that coarse focal scarring begins in early childhood in most cases and is due to infection. In only 3 of the 29 damaged kidneys in our infant group, however, were the changes of a focal nature; in the remainder the damage was generalized. This would suggest that the hydrodynamic effect of vesicoureteric reflux is an important factor in producing renal damage in the prenatal and neonatal period. It seems probable that the continuing insult of the refluxing ureter may result in depressed growth and atrophy of the sensitive developing renal tissue.

Though most of our patients with gross vesicoureteric reflux suffered from recurring infection in the follow-up period there were two examples of progressive generalized renal damage in children who had remained free of infection during the five-year follow-up period and whose initial pyelograms had shown no evidence of renal damage. In both cases regular bacteriological examination of urine had been negative over the follow-up period. Fig. 1 shows one of these cases.

The evidence that has resulted from this follow-up study would indicate that the contracted atrophic "pyelonephritic" kidney of children and adults is the result of gross vesicoureteric reflux in infancy. We have also shown that if gross vesicoureteric reflux is allowed to persist progressive renal damage may occur in apparently normal infant kidneys as well as in those showing initial damage. It would appear, therefore, that the grossly refluxing ureter of infancy is potentially dangerous to the kidney and should be surgically corrected as soon as possible. There would not appear to be any indication to correct moderate or slight reflux.

\section{REFERENCES}

Hodson, C. J. (1965). Proceedings of the Royal Society of Medicine, 58, 785.

Hodson, C. J., Drewe, J. A., Karn, M. N., and King, A. (1962). Archives of Disease in Childhood, 37, 616.

Little, P. J., McPherson, D. R., and de Wardener, H. E. (1965). Lancet, 1, 1186.

Scott, J E. S., and Stansfeld, J. M. (1968). Archives of Disease in Childhood, 43, 323.

Shannon, F. 'T., Sepp, E., and Rose, G. R. (1969). Australian Paediatric fournal, 5, 97.

Stephens, D. S. (1963). Fournal of the College of Radiologists of Australasia, $7,17$.

\title{
Use of Oral Mannitol in the Oedematous Patient
}

\author{
J. W. JAMES, ${ }^{*}$ M.R.A.C.P. ; R. A. EVANS, $†$ M.R.A.C.P.
}

British Medical fournal, 1970, 1, 463-465

Cummary: Oral mannitol 200 g. was given on 24

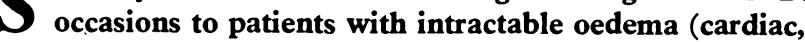
renal, or hepatic) and produced a mean weight loss of $3 \mathbf{~ k g}$. The procedure was found to be a safe, rapid, and effective method of treating oedema, and it should be used when diuretic therapy proves ineffective, particularly in the presence of hyponatraemia.

\section{Introduction}

Most oedematous patients respond to bed rest, salt restriction, digitalization (if indicated), and moderate doses of diuretics.

* Medical Officer.

†Specialist Resuscitation.

Repatriation General Hospital, Concord, New South Wales, Australia.
Some who are refractory to these measures respond to large doses of potent diuretics (Maher and Schreiner, 1965). If even these fail, mechanical methods of fluid removal become necessary-peritoneal dialysis, abdominal paracentesis, or even Southey tubes.

This paper describes our experience with oral mannitol in a group of patients refractory to medical therapy and attempts to define its place in the treatment of oedema.

\section{Patients and Methods}

Sixteen patients were treated with oral mannitol on 25 occasions. Nine had congestive cardiac failure, six had advanced renal failure, and one had cirrhosis of the liver. All patients, however, had both cardiomegaly and some degree of azotaemia, the lowest blood urea level being $70 \mathrm{mg}$. $/ 100 \mathrm{ml}$. They 
were referred from general medical wards after failing to respond to conventional therapy. Most were dyspnoeic at the time of referral and the mannitol administration was often an urgent procedure.

Mannitol $200 \mathrm{~g}$. dissolved in a litre of water was taken over a two-hour period (if taken more rapidly vomiting usually ensued). During the profuse diarrhoea that followed the patients were allowed to sit on a bedside commode. No fluids were allowed for 24 hours, and then moderate fluid restriction (usually 1 litre per day) was continued unless a sustained improvement was shown.

The diarrhoea fluid was collected in a tared plastic bucket and weighed. Samples were taken, and sodium and potassium estimations were made with an E.E.L. flame photometer. A Technicon AutoAnalyzer was used for estimating the blood urea and serum electrolytes; these were estimated in all patients before administration of mannitol and on the following day in 15 patients.

\section{Results}

Diarrhoea began half an hour after the first glass of mannitol and continued for about six hours. There was no associated colic, and though the patients were tired by the end of the procedure they were not distressed. As the first call to stool follows a significant reduction in blood volume, even severely dyspnoeic patients with cardiac failure were able to sit on a bedside commode. In one patient a fall in systolic blood pressure from 120 to $80 \mathrm{~mm}$. $\mathrm{Hg}$ near the conclusion of the diarrhoea was corrected by his remaining horizontal for about three hours.

The volume of faecal fluid varied from 1.9 to 4.71 . with a mean of 2.91 . This includes the original litre ingested, and so indicates a mean fluid loss of 1.91 . The weight lost by the patient was higher, the mean being 3.0 (range 0.9 to 7.3 ) $\mathrm{kg}$.

The faecal fluid had a mean sodium concentration of 31 (range 12 to 59 ) $\mathrm{mEq} / \mathrm{l}$. and a mean potassium concentration of 10 (range 5 to 20 ) $\mathrm{mEq} / \mathrm{l}$. Following the procedure the serum sodium rose by a mean of 6 (range -8 to $+15) \mathrm{mEq} / \mathrm{l}$. and the serum potassium fell by a mean of 0.5 (range -1.9 to +0.8$) \mathrm{mEq} / \mathrm{l}$, as shown in the Chart. The blood urea fell by a mean of 5 (range -72 to +20 ) mg. $/ 100 \mathrm{ml}$.

After mannitol three patients (all with cardiac oedema) responded to diuretics which had previously been ineffective. The remainder were treated with large doses of ethacrynic acid, fluid restriction, and mannitol as required.

Four examples are cited to illustrate the use of mannitol in different situations.

\section{Case Reports}

Case 1.-A 44-year-old man with advanced chronic glomerulonephritis was admitted to hospital because of dyspnoea and oedema, which was increasing despite salt restriction, digoxin, and ethacrynic acid $1,000 \mathrm{mg}$./day. On admission there was gross congestive cardiac failure and the blood pressure was $190 / 125 \mathrm{~mm}$. Hg. Investigations included: blood urea $210 \mathrm{mg} . / 100 \mathrm{ml}$., serum creatinine $9.6 \mathrm{mg} . / 100 \mathrm{ml}$, and serum sodium $125 \mathrm{mEq} / 1$. Oral mannitol $200 \mathrm{~g}$. produced a weight loss of $4.6 \mathrm{~kg}$., partial resolution of the oedema, and a rise in serum sodium to $132 \mathrm{mEq} / \mathrm{l}$. Four days later the mannitol was repeated with a further weight loss of $4.0 \mathrm{~kg}$., disappearance of the signs of cardiac failure, and a fall in blood pressure to $160 / 90 \mathrm{~mm}$. Hg. He was then discharged with his original therapy except that fluids were now restricted to 1 1./day. There was no change in serum creatinine during the admission.

Case 2.-A 72-year-old man with congestive cardiac failure had been deteriorating at home despite a regimen that included frusemide $240 \mathrm{mg}$./day. On admission he was dyspnoeic and had gross heart failure with anasarca. His blood urea was $76 \mathrm{mg} . / 100 \mathrm{ml}$. and serum sodium $135 \mathrm{mg} . / 100 \mathrm{ml}$. As there was no response to an immediate dose of ethacrynic acid $200 \mathrm{mg}$. he was given mannitol $200 \mathrm{~g}$., which relieved the dyspnoea. Over the next eight days the ethacrynic acid was increased till a diuresis occurred when the daily dose was $800 \mathrm{mg}$. During this time it was necessary to give mannitol on two further occasions to control dyspnoea.

Case 3.-A 47-year-old man with chronic glomerulonephritis was admitted when a low protein diet did not adequately control his azotaemia. On admission his blood urea was $280 \mathrm{mg} . / 100 \mathrm{ml}$. and creatinine $20 \mathrm{mg} . / 100 \mathrm{ml}$. After taking a modified Giovannetti diet for three weeks his blood urea fell to $160 \mathrm{mg}$. $/ 100 \mathrm{ml}$. (with no change in serum creatinine) and he felt well. He became oliguric, however, and developed fluid retention with orthopnoea and oedema. This could not be controlled by restriction of salt and water, and there was no response to ethacrynic acid $800 \mathrm{mg} . /$ day. Mannitol $200 \mathrm{~g}$. by mouth resulted in a loss in weight of $2.6 \mathrm{~kg}$. and relief of symptoms. His weight again increased so the mannitol was repeated, and this time, owing to his better acceptance of fluid restriction, the weight loss was maintained. He then remained in fair condition till he could be accepted in a chronic dialysis programme some weeks later.

Case 4.-A 69-year-old woman with chronic pyelonephritis had required monthly blood transfusions of two units of packed cells to control a hypoplastic anaemia. During an acute episode of pyelonephritis she was anuric for several days and required peritoneal dialysis; at the time of writing she was asymptomatic despite a blood urea of $160 \mathrm{mg} . / 100 \mathrm{ml}$. and serum creatinine of $10 \mathrm{mg} . / 100 \mathrm{ml}$. Since the dialysis, however, her monthly blood transfusions were always accompanied or followed by pulmonary oedema. For the past six months she has therefore been given oral mannitol $150 \mathrm{~g}$. before each transfusion, and has had no dyspnoea; her stay in hospital for each transfusion has been reduced to 36 hours.
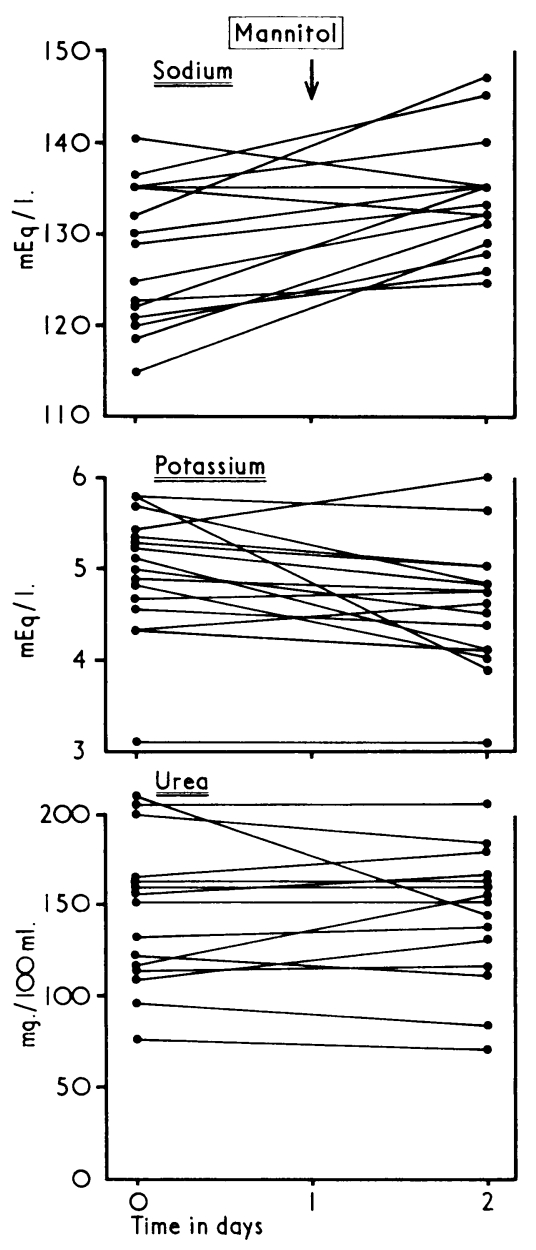

Effect of mannitol by mouth on serum sodium, serum potassium, and blood urea concentrations. 


\section{Discussion}

Though the use of mannitol intravenously has been extensively studied, little interest has been shown in its remarkable properties in the gut. Carr and Krantz (1953) showed that oral mannitol produced diarrhoea in rats; the mechanism has been partly elucidated by Hindle and Code (1962), who found that in the isolated duodenum of dogs hypertonic mannitol caused a profuse secretion of water and sodium into the lumen to produce an isosmotic solution. In the ileum this did not occur, and there was merely a slow absorption of both water and mannitol. The clinical use of osmotic diarrhoea has previously been made by Gertman et al. (1966) in treating ascites due to cirrhosis of the liver, and by Giovannetti et al. (1968), who used a sorbitol-mannitol mixture for correcting salt and water retention in uraemic patients.

As a $5.5 \%$ solution of mannitol is isosmotic with plasma the oral administration of 1 litre of $20 \%$ mannitol might be expected to produce almost 4 litres of diarrhoea fluid. There are, however, many variable factors such as absorption of mannitol from the gut, secretion of sodium into the gut, and perhaps inadequate time to achieve isosmolality. In practice, though the faecal volume varied considerably the mean of 2.9 litres was less than that predicted.

The commonest causes of failure were vomiting (due to too rapid ingestion of the mannitol) and failure of fluid restriction during the ensuing 24 hours. Abdominal colic and electrolyte disturbances did not occur; indeed, when hyponatraemia was present the serum sodium usually rose significantly (as shown in the Chart).

Oral mannitol should be used when diuretic therapy proves ineffective, particularly in the presence of hyponatraemia. In these circumstances it is used essentially as an alternative to peritoneal dialysis for those patients whose azotaemia is not severe enough to justify dialysis. Such patients include those incapacitated by congestive cardiac failure (Cases 1 and 2). It can be used in severe renal failure to correct overhydration (Case 3) and as a preliminary to infusion of sodium bicarbonate solution or blood (Case 4). Where the azotaemia itself is severe-for example, blood urea above $300 \mathrm{mg} . / 100 \mathrm{ml}$.dialysis is of course necessary.

\section{REFERENCES}

Carr, C. J. and Krantz, J. C., jun. (1938). Fournal of Biological Chemistry, 124, 221.

Gertman, P. M., Gagnon, O., and Iber, F. L. (1966). Fournal of the American Medical Association, 197, 257.

Giovannetti, S., Maggiore, Q., and Giusti, C. (1968). In Nutrition in Renal Disease, edited by G. M. Berlyne, p. 141. Edinburgh, Livingstone.

Hindle, W., and Code, C. F. (1962). American fournal of Physiology, 203, 215.

Maher, J. F., and Schreiner, G. E. (1965). Annals of Internal Medicine, 62,15 .

\title{
Impaired Glucose Tolerance : A Late Effect of Insulin Shock Treatment
}

\author{
RICHARD HUNTER,* M.D. ; MURIEL JONES, † M.B., PH.D. ; B. A. L. HURN, \\ CATHERINE DUNCAN, $\$ B.SC.
}

\begin{abstract}
Cummary: Glucose tolerance tests were performed in a $\checkmark$ group of patients in a mental hospital who had been treated with insulin shock and in a matched control group. Five out of $31(16 \%)$ patients in the insulintreated group and 1 out of $22(5 \%)$ controls had "diabetic" blood sugar curves. Median blood sugar values were significantly higher at 60 minutes and later in the insulin-treated group, as were mean blood sugar values when the "diabetic" patients were excluded. Small amounts of plasma insulin-binding antibody were found in two insulin-treated patients. In the absence of any other clear-cut explanation, it is suggested that in some patients massive doses of insulin by injection may leave diminished tissue responsiveness to insulin as a long-term after-effect.
\end{abstract}

\section{Introduction}

Insulin shock treatment (I.S.T.) as a method of reducing mental disturbance by the repeated induction of hypoglycaemic coma was introduced on a large scale in the 1930s (Wortis, 1959). It flourished again for a decade after the war, when

* Consultant Psychiatrist, Friern Hospital, London N.11.

† Senior Registrar, Exe Vale Hospital, Exminster, Devon.

$¥$ Clinical Pathologist, the Wellcome Research Laboratories, Bec'zenham, Kent.

$\int$ Member of Scientific Staff, M.R.C. Statistical Research and Services Unit, University College Hospital Medical School, London W.C.1. literally thousands of patients called "schizophrenic" were submitted to it. Though not "a cure," wrote Mayer-Gros3 (1953), a persistent advocate, “ it supports Nature's curative tendencies." Sakel (1956), its chief protagonist, explained that it acted by causing "an intensification of the tonus of the parasympathetic end of the autonomic nervous system, by blockading the nerve cell" (sic). This effect by "strengthening the anabolic force ... induces restoration of the normal function."

Many remained sceptical because of "the wide divergence in results reported by different investigators" (Jessner and Ryan, 1941). Others were soon convinced that its place in the treatment of "schizophrenia" was "firmly established" (Sargant and Slater, 1948). Opposing views were aired in the correspondence following the paper by Bourne (1953) under the title "The Insulin Myth." With the introduction of phenothiazine compounds discussion died down and soon insulin shock treatment, in all but a few isolated centres, was relegated to the limbo of psychiatric treatments which were supposed to have worked.

Insulin shock treatment consisted in giving daily intramuscular injections of crystalline insulin after overnight fast on five or six days a week, starting with a small dose and increasing until hypoglycaemic coma was induced. The dose was then adjusted to make coma last half to one hour. Patients were resuscitated by gastric or intravenous infusion of sugar: 